\title{
The Integration of Personality Education in the Teaching of Etiquette in Colleges
}

\author{
Zuo Xiaoyu \\ Hainan College of Economics and Business, Haikou, Hainan, China \\ email:791171843@qq.com
}

Keywords: personality education; colleges; etiquette teaching; integration

\begin{abstract}
This paper mainly studies the importance, ways and strategies of integrating the personality education into the students' etiquette teaching in higher vocational colleges, hoping that higher vocational colleges should pay attention to the personality education of students when they teach etiquette to students. They should not only cultivate highly skilled and professional talents, but also make them have high quality, laying a solid foundation for their future development.
\end{abstract}

\section{Introduction}

The Chinese nation is a state of etiquette. Since ancient times, China has paid more attention to the etiquette education for students. Confucius is the greatest educator in China, he not only put forward the idea of "provide education for all people without discrimination", but also placed "ritual" teaching in a prominent position for students' education. Higher vocational colleges are places for cultivating high-end skilled personnel for China's socialist modernization. When educating students about knowledge and skills, it is also very important to strengthen etiquette education for students. Many higher vocational colleges in China are paying more attention to students' skills teaching when they educate students. They have trained a large number of skilled talents of production, service, and managerial for social production and service, but they have neglected the etiquette education for students, which has had an adverse effect on the healthy development of students. Good etiquette is the necessary quality for students to enter the society and the workplace. In higher vocational colleges, when we educate students, we should not only enhance their professional quality education, but also enhance their professional etiquette education, so that students can learn etiquette and norms to be with people and learn to behave.

\section{The necessity of integrating personality education into Higher Vocational etiquette teaching}

Etiquette refers to the spirit of maintenance ceremony, the way to coordinate interpersonal relationships, and the summary of activities. There are many forms of expression, such as language etiquette, grooming, courtesy, etiquette, etc., which are mainly embodied in interpersonal communication and can profoundly responding to a person's spiritual connotation, and is the unity of the person's intrinsic quality and external quality. Humans are the subject of transformation of nature and society. The quality of humans not only has a great impact on the quality of social life, but also affects the harmonious development of human society. Personality is the core of morality. If a person does not have a sound personality as a basis, etiquette will loss the ground to grow. A truly high-quality person first manifests himself as the perfection of personality, the integrity of his personality and the etiquette are both influential and indispensable. Conducting etiquette teaching to higher vocational students can awaken their dignity. Respect is the core principle of etiquette education and is the most important virtue in the process of human interaction. In etiquette, there is a very strict hierarchical order. For example, the subordinates should respect their superiors and younger generations should respect their elders. Conversely, superiors should also be polite to their subordinates, and the elders should also care for younger generations, so that mutual respect between the two parties can be obtained. Only in good etiquette practice, can talents feel their 
dignity better. Only the awakening of human dignity can make people more humanity.

Self-discipline is also a principle advocated by etiquette, and self-discipline is the highest level of personality. Under the principle of self-discipline, everyone will establish an internal code of ethics and conduct in their own hearts. Social norms include legal norms and moral norms. Legal norms refer to systems that use the external constraints of the law to impose restrictions on human behavior. Moral norms are non-legal norms and are not mandatory. Etiquette belongs to a type of moral norms [1]. In the long course of development, etiquette is constantly improved with the development of society. In etiquette culture, the personality is mainly molded from the aesthetic point of view. Any form of etiquette contains many aesthetic requirements, reflecting the common aesthetic taste and appreciation habits of human beings. Therefore, the etiquette culture is from the aesthetic point of view to influence people and attract people. Etiquette culture can combine moral education and aesthetic education organically together, imperceptibly cultivate people's temperament, purify the human mind, and have a greater impact on people's thinking and behavior, and promote the improvement of personality. When educating higher vocational students, if they simply conduct moral education for students and pay more attention to the rational education of students, it is difficult to penetrate the students' thinking and it is difficult for students to change their behavior. There is a great difference between the education of the etiquette culture and the moral education of the students. Etiquette culture education not only emphasizes the rational education of students, but more importantly, it can regulate people's behavior from many microscopic perspectives, such as speaking and behavior, eating and living, dealing with people, etc., which promotes the promotion of human cultivation, improves people's behavior and creates a perfect personality. Therefore, in the course of etiquette education for higher vocational students, it is necessary to strengthen the personality education of students so that the better teaching effect can be achieved.

\section{The way and strategy of personality education in the teaching of Higher Vocational etiquette}

\subsection{Strengthening the construction of the etiquette and culture in schools}

Etiquette is an important type of culture that has gradually formed and improved in the course of human development. Campus etiquette culture is a concrete manifestation of teachers and students' spiritual culture. A good campus culture can generate strong forces, inspire people and make them inspiring. Therefore, strengthening the construction of campus etiquette culture is an important part of strengthening etiquette education for higher vocational students [2]. Higher vocational colleges should incorporate etiquette and standardization requirements into the school's various regulations and management systems, formulate and improve the college students' daily behavior standards, use the daily behavior norms to guide the college students' ideas and behaviors, to create a positive atmosphere of the campus culture in Higher Vocational colleges. Schools and each institutions should also set up a number of college etiquette societies, so that the etiquette communities undertake a variety of activities within the school etiquette services. When students use ceremonial norms to treat people, they can also enhance their mastery of ritual knowledge through practical training. Schools can also carry out a variety of interactions for students on various topics, such as speech contests, debate games, and selection of campus etiquette stars, so that students can participate in campus etiquette through multiple channels and promote civilized courtesy, forming a good atmosphere of campus civilization etiquette.

\subsection{Teachers should give full play to the role model of civilized etiquette}

The role of model is very large. In the etiquette teaching of students, the teacher's role of model and demonstration can greatly affect the student's etiquette, personality and self-cultivation. Therefore, higher vocational teachers must constantly improve their own etiquette qualities and strive to become a good model for students to learn. If teachers want to set a good model for their students, they must first ideologically attach great importance to their role as role models, 
profoundly recognize the importance of etiquette, care about the healthy growth of students and the country's civilization, and regard civilized etiquette as a kind of self-consciousness. Civilization etiquette slowly became a habit, and ultimately allowed civilized etiquette to naturally emerge from teachers' speeches and behaviors, fully embodying teachers' good personal accomplishments. When teachers communicate with students, they must communicate with students under the principle of equality and respect, and think more from the perspective of the students. If teachers always communicate with students in a condescending manner, it is difficult for students to eliminate the alertness of teachers. Only when the students feel that the teachers care about them can they respect the teachers, worship the teachers, and use the teachers as examples for their studies to correct their bad behavior. However, teachers' respect for students is not equal to the indulgence of students. When teachers are teaching students, they still have to make strict demands on students. In peacetime, the relationship with students should be as equal and harmonious as possible. Dressing is an important part of etiquette. Therefore, teachers must treat their usual dress appropriately, must meet the image of the teacher, give students a feeling of beauty, and promote the improvement of students' aesthetic ability. When teachers teach students, they must look beautiful, natural and poised. However, do not pursue grades or brand names to prevent students from following the trend and competitions to bring unhealthy tendencies in schools.

\subsection{Perfect the curriculum system of etiquette in Higher Vocational Colleges}

In higher vocational colleges, some students major in technology, and some students major services. No matter what major they are studying, we should pay attention to the etiquette teaching to students. Taking the civil aviation service majors as an example, when conducting etiquette teaching for civil aviation service major students, we must set up etiquette teaching courses according to the students' major training objectives and practical needs. For example, some students do flight attendants after graduating, and some students do the ground service work, some students do ticket sales work, etc. In order to improve the ability of students to adapt to employment after graduation, higher vocational colleges should train high-skilled personnel who can engage in flight attendance services and can engage in civil aviation ground services or hotel management services [3]. When conducting etiquette teaching to civil aviation service majors, etiquette teaching can be divided into basic etiquette teaching, ground service etiquette teaching, sales customer service etiquette teaching. When conducting basic etiquette teaching, we should pay attention to students' grooming and instrument training, speech manners, and social etiquette. The ground service etiquette teaching mainly allows students to learn related etiquette knowledge and skills in the work scene. The teaching of customer service etiquette for the students mainly lies in the ability to expand the students' employment and improve their professional ability. In the etiquette teaching of students, we must integrate the personality education of students so that we can cultivate students' good accomplishments and connotations and lay a solid foundation for the healthy development of students. Higher vocational colleges often employ ceremonial teaching experts to conduct ceremonial lectures for students in order to teach students how to adapt to the new environment and how to conduct self-management. Within the scope of the school, you can also set up some elective courses such as daily etiquette and social etiquette for the younger students. For senior students or students who are about to graduate, courses such as job-seeking etiquette and interview etiquette are offered to help students with learning needs and career planning.

\subsection{Developing a combination of theoretical and practical teaching models for students}

In the traditional higher vocational etiquette teaching, teachers are preaching. Students receive passive etiquette knowledge, and teachers explain and demonstrate etiquette regulations for students according to their teaching content. Even if there are some training courses, the teacher leads the students in basic squat exercises. Practical teaching is often limited by teaching hours, class sizes, and teaching venues, and effective ritual practice teaching cannot be conducted. In order to enhance the effect of etiquette teaching on students, the school must change the traditional etiquette teaching mode, integrate personality education into etiquette teaching, adopt theory and practice methods to 
carry out etiquette teaching to students, and enable students to fully experience etiquette teaching content in practice, to fully mobilize the students' enthusiasm and initiative [4]. Taking the major of flight attendants in Higher Vocational Colleges as an example, it is the most basic etiquette training content for the students to carry on the standing squat training. Students who want to become a qualified flight attendant must behave gracefully and decently during the course of their work, and behave in a manner that suits their passengers. Taking catering etiquette as an example, when catering service etiquette is taught to students, there is a big difference between aircraft cabin catering etiquette and hotel catering etiquette. When teachers are teaching catering service etiquette to flight attendants, if they follow the catering etiquette of ordinary hotels to teach students, and it is difficult to provide greater help to the employment of flight attendants. In catering service etiquette teaching for flight attendants, catering etiquette can be divided into several parts, teaching etiquette teaching of catering service to students according to different parts. For example, dining car placement, wine and drink delivery service etiquette, dining etiquette, conflict and complaint solutions, etc. And guiding students to simulate cabin scenarios for role-playing or scenario training. Students who do not participate in training can serve as passengers to observe, comment on their services, etc. Finally, the teacher makes a summary or supplement. In the process of etiquette teaching for students of higher vocational colleges, integrating personality education for students and using the combination of theory and practice to teach students can have a very significant effect. It can not only greatly enhance students' enthusiasm and initiative in etiquette learning, but also enable students to understand more deeply the various etiquette, promote the rapid improvement of students' professional knowledge and skills, and lay a solid foundation for the future development of students.

\section{Conclusions}

Etiquette teaching is an important part of higher vocational colleges in teaching students. Higher vocational colleges must pay attention to the etiquette education of students when they are teaching students with professional knowledge, and integrate personality education into the etiquette education of students to promote the improvement of student personality and make students better adapt to the needs of social development and gain a better future.

\section{References}

[1] Hao Yaodan, Dong Qi. The practice and exploration of the penetration of personality education in the teaching of Higher Vocational etiquette -- Based on the perspective of the civil aviation service majors[J]. Vocational \& Technical Education Forum, 2014(15):176-179.

[2] Dong Jin. The integration of healthy personality education in the ideological and political teaching of College Students[J]. Educational Science: Full text edition, 2016(12): 265-265.

[2] Wang Xi, Gao Bin. The integration of healthy personality education in the ideological and political teaching of College Students[J]. Journal of China Youth University for Political Science, 2013(1):153-156.

[4] Zhang Xiulan. The practice and exploration of the permeation of personality education in the teaching of etiquette in Higher Vocational Tourism[J]. Manager’ Journal, 2016(17):142-143. 